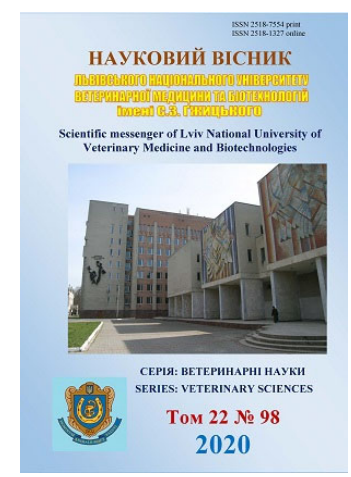

Науковий вісник Дьвівського національного університету ветеринарної медицини та біотехнологій імені С.3. Гжицького. Серія: Ветеринарні науки

\author{
Scientific Messenger of Lviv National University \\ of Veterinary Medicine and Biotechnologies. \\ Series: Veterinary sciences
}

UDC 619:616.07:619:616.1:636.7

\title{
Electrocardiographic evaluation of cardiac activity in dogs with CHF
}

\author{
R. M. Trofimiak, L. H. Slivinska \\ Stepan Gzhytskyi National University of Veterinary Medicine and Biotechnologies, Lviv, Ukraine
}

Article info

Received 10.04.2020 Received in revised form 13.05 .2020 Accepted 14.05.2020

Stepan Gzhytskyi National University of Veterinary Medicine and Biotechnologies, Pekarska Str., 50, Lviv, 79010, Ukraine. Tel. +38-097-950-55-06 E-mail:fiosfiona@gmail.com
Trofimiak, R. M., \& Slivinska, L. H. (2020). Electrocardiographic evaluation of cardiac activity in dogs with CHF. Scientific Messenger of Lviv National University of Veterinary Medicine and Biotechnologies. Series: Veterinary sciences, 22(98), 100-107. doi: 10.32718/nvlvet9818

An important pathogenetic link of the progression of chronic heart failure of various genesis is the development of arrhythmias. They significantly complicate the course of CHF, because they lead to decreased cardiac output and increased hypoxia. The aim of our study was to investigate and evaluate the electrical activity of the heart of dogs with CHF. The research was performed on the basis of the private veterinary center "Vetmed" (Lviv) in 2016-2017. The study included 36 dogs of different breeds, ages, sexes with symptoms of chronic heart failure. A standard six-lead electrocardiogram (ECG) was recorded in all dogs in the right lateral position using an electrocardiograph "Vet ECG Ve-300" (speed 50mm/s, sensitivity of the device $\operatorname{lm} V=10 \mathrm{~mm}$ ). The obtained data were compared with reference values, and also took into account the variation of individual indicators depending on body weight. According to the results of our study, it was found that the frequency of arrhythmias in dogs with CHF is $75.0 \%$, of which $8.3 \%$ - lifethreatening, $38.9 \%$ of the examined animals needed treatment, and $27.8 \%$ - annual ECG monitoring. The signs of remodeling processes are found in $63.9 \%$ of sick dogs, signs of ischemia - in $25 \%$ and only in $2.8 \%$ of animals - ECG without changes. The structure of arrhythmia in dogs with CHF is dominated by sinus tachycardia $(47.2 \%)$, sinus bradycardia $(8.3 \%)$, ventricular arrhythmias $(5.6 \%)$, atrial fibrillation $(5.6 \%)$, ventricular tachycardia (2.8\%). Among conduction disorders, we register intraatrial blockade $(13.9 \%)$ and $A V$-blockade of the first degree (8.3\%). In $13.9 \%$ of animals ECG signs of fibrosis, ischemia are combined with changes in the size of the heart chambers. The results of our study show that a significant number of dogs with CHF have arrhythmias and conduction disorders. In order to improve diagnosis and treatment, the prospect of further research is to establish an association between ECG and echocardiographic changes in dogs with $\mathrm{CHF}$, which can be both a cause of $\mathrm{CH}$ and its consequence and a predictor of an unfavorable prognosis.

Key words: chronic heart failure, a dog, electrocardiography, arrhythmias, ischemia, fibrosis.

\section{Електрокардіографічна оцінка серцевої діяльності у собак із синдромом XCH}

\author{
Р. М. Трофім'як, Л. Г. Слівінська
}

Львівський національний університет ветеринарної медицини та біотехнологій імені С. 3. Гжсиького, м. Львів, Україна

Важливою патогенетичною ланкою у прогресуванні хронічної сериевої недостатності різноманітної генези є розвиток аритмій. Вони значно ускладнюють перебіг ХСН, оскільки призводять до зниження серчевого викиду та наростання гіпоксї. Метою роботи було дослідити та оцінити електричну активність серия собак із синдромом ХСН. Дослідження виконувались на базі приватного ветеринарного центру “Ветмед” (м. Львів) у 2016-2017 рр. Об'єктом досліджень були 36 собак різних порід, віку, статі із симптомами хронічної сериевої недостатності. Тваринам було проведено електрокардіографічне дослідження в правому боковому положенні за допомогою електрокардіографа “Vet ECG Ve-300” (швидкість 50 мм/с, чутливість апарата 1 мB = 10 мм). ЕКГ реєстрували у стандартних та підсилених відведеннях від кіниівок без застосування фільтрів. Отримані дані порівнювали з референтними значеннями, а також враховували варіювання окремих показників залежно від маси тіла. Згідно з результатами 
нашого дослідження встановлено, щя частота аритмій у собак із ХСН складає 75,0\%, із них 8,3\% - загрозливі для життя, 38,9\% із обстежених тварин потребували лікування, а 27,8 \%- щорічного ЕКГ-моніторингу. Дотичні ознаки процесів ремоделювання виявляємо у 63,9\% хворих собак, ознаки ішемї - у $25 \%$ та лише у 2,8\% тварин - ЕКГ без змін. У структурі порушення ритму в собак за ХСН переважають синусова тахікардія (47,2 \%), синусова брадикардія (8,3 \%), илуночкові екстрасистоли (5,6\%), фібрилячія передсердь (5,6\%), шлуночкова тахікардія (2,8\%). Порушення провідності реєструємо у вигляді внутріпередсердної блокади (13,9\%) та АВ-блокади I ступеня (8,3\%). У 13,9\% тварин ЕКГ-ознаки фіброзу, імемії поєднуються із змінами розмірів камер серия. Результати нашого дослідження свідчать, щчо значна кількість собак із ХСН має порушення сериевого ритму і провідності. Для покращення діагностики та лікування перспектива подальших досліджень полягає у встановленні взаємозв'язку між ЕКГ- та ЕхоКГ-змінами у собак із синдромом ХСН, які можуть бути як причиною СН, так $і$ ї̈ наслідком та предиктором несприятливого прогнозу перебігу захворювання.

Ключові слова: хронічна серцева недостатність, собака, електрокардіографія, аритмї, ішемія, фіброз.

\section{Вступ}

Синдром хронічної серцевої недостатності розвивається в результаті захворювань серцево-судинної системи (кардіоміопатії, міокардити, хвороби клапанів, дирофіляріоз, системна артеріальна гіпертензія) i супроводжуються порушенням діастолічної та/або систолічної функції серця. Внаслідок хронічної гіперактивації нейрогуморальних систем виникають структурно-функціональні зміни у міокарді із порушенням його фізіологічних властивостей. Це може бути передумовою для розвитку аритмій (Illarionova, 2012). Згідно $з$ даними Noszczyk-Nowak A. (NoszczykNowak et al., 2017), частота появи патологічних аритмій у загальній популяції собак становить 39,6 \%, а за результатими досліджень Kumar А. та Aptekmann K. (Aptekmann et al., 2010; Kumar et al., 2014) - 21,9 \% та 27,8 \% відповідно. Натомість, інцидентність фізіологічних аритмій складає 8,0 \% (Noszczyk-Nowak et al., 2017).

Найпоширенішим видом суправентрикулярних аритмій (СВА) є фібриляція передсердь (ФП), іiі частка складає 33,7 \% від усіх патологічних аритмій (Noszczyk-Nowak et al., 2017). За даними інших авторів (Aptekmann et al., 2010; Kumar et al., 2014), у собак, крім миготливої аритмії, також рівнозначно діагностують синусову тахікардію. Причинами іiі розвитку вважають (Aptekmann et al., 2010) фізіологічний стан собак - стрес, страх.

Ряд дослідників у своїх роботах (Kumar et al., 2014; Noszczyk-Nowak et al., 2017) проводили статистичний аналіз поширення аритмій відповідно до віку, статі, ваги, породи. Так, аритмії частіше реєструють у самок $(22,98 \%)$ та у тварин 1-3-річного віку, найвищий відносний ризик їхньої появи у собак породи померанський шпіц $(1,76)$ (Kumar et al., 2014). У 65 \% самців 3 віковим діапазоном понад 6 років діагностують суправентрикулярні аритмії. Здебільшого це тварини вагової категорії 11-25 кг, найчастіше породи лабрадор-ретривер та німецькі вівчарки (7,9\%) (Noszczyk-Nowak et al., 2017).

За останне десятиліття проведено велику кількість досліджень щодо порушень електричної активності міокарда за конкретних серцевих захворювань. Частка міксоматозної дегенерації мітрального клапана складає (ендокардіоз мітрального клапана, ЕМК) до 75 \% від усіх серцевих хвороб собак (Illarionova et al., 2006; Rudenko, 2007; Baisan et al., 2016; Bogucki \& Noszczyk-Nowak, 2017; Keene et al., 2019). У дрібних порід із прогресуванням ЕMК (Kim et al., 2017; Car- valho et al., 2018) зростає ймовірність розвитку CBA, поліморфних шлуночкових аритмій, а у великих і середніх (Jung et al., 2016; Keene et al., 2019) - у 52 \% випадків виникає ФП. Окрім того, у собак із прогресуванням ЕМК пролонгація коригованого інтервалу QT та його дисперсія є ранніми індикаторами розладів реполяризації в міокарді та факторами ризику розвитку злоякісних шлуночкових аритмій (Bruler et al., 2018).

Поширеність дилятаційної кардіоміопатії (ДКМП) у загальній популяції собак становить 0,5 \% (Baisan et al., 2016) і частіше зустрічається серед великих та гігантських порід (24-45\%), зокрема серед доберманів, боксерів, ньюфаундлендів, німецьких вівчарок тощо (Vollmar, 2000; Morales et al., 2001; Martin et al., 2009; Vess, 2016; Dutton \& López-Alvarez, 2018). Найпоширенішим видом порушень серцевого ритму $\epsilon$ ФП, яку діагностують у 45-97,2 \% собак із симптомами XCH (Vollmar, 2000; Morales et al., 2001; Martin et al., 2009). Встановлено, що із зростанням класу ХCH за ДКМП ймовірність виникнення миготливої аритмії зростає у 3,27 раза (Rudenko, 2007). Характерною рисою в патогенезі ДКМП є ризик появи т. зв. “самостійних ФП” у собак ще в латентній стадії захворювання, що можуть призвести до летальних наслідків (Vollmar, 2000; Martin et al., 2009; Vess, 2016; Dutton \& López-Alvarez, 2018). Однак, у боксерів, ньюфаундлендів та ердельтер'єрів за ДКМП значно частіше діагностують шлуночкові дизаритмії (Morales et al., 2001; Meurs, 2017; Dutton \& López-Alvarez, 2018).

Вивчення особливостей прояву аритмій у собак із синдромом ХCH та їхнього впливу на прогресування серцевої недостатності $\epsilon$ актуальною проблемою ветеринарної медицини. Своєчасне їх виявлення визначає прогноз подальшого перебігу чи закінчення основної хвороби та $є$ однією з передумов для корекції медикаментозної терапії у тварин.

Мета роботи полягає в дослідженні та оцінці електричної активності серця у собак із прогресуючою хронічною серцевою недостатністю.

\section{Матеріал і методи досліджень}

Робота виконувалася на базі приватного ветеринарного центру “Ветмед”, (м. Львів) у 2016-2017 рр. Об'єктом дослідження були 36 собак різних порід (21 самець, 15 самок) з ознаками хронічної серцевої недостатності. Віковий діапазон тварин складав 4-13 $(9,4 \pm 0,36)$ років, маса тіла була в межах 2,1-71 $(22,6 \pm 3,06)$ кг. Під час дослідження було сформовано 
дослідну групу тварин, відбір до якої здійснювався за результатами даних анамнезу та проведеного загальноклінічного огляду. Тваринам було проведено електрокардіографічне обстеження в правому боковому положенні за допомогою електрокардіографа "Vet ECG Ve-300” (швидкість $50 \mathrm{~mm} / \mathrm{c}$, чутливість апарата $1 \mathrm{mB}=10$ мм). ЕКГ реєстрували в стандартних (за Ейнтговеном I, II, III) та підсилених (за Гольдбергом aVR, aVL, aVF) відведеннях від кінцівок без застосування фільтрів згідно з загальноприйнятими рекомендаціями (Tilley, 1992). Матеріалом слугували електрокардіографічні записи активності серця протягом 5 хвилин. Аналіз електрокардіограм проводили за допомогою електрокардіографічної лінійки, спеціальних розрахункових формул за встановленими алгоритмами (Illarionova, 2006; Paslawska \& Kurski, 2008). Отримані дані порівнювали 3 референтними значеннями (Cvilihovs'kij et al., 2010). При проведенні дослідження також враховували варіювання окремих показників від маси тіла (Rudenko, 2009). Зважування тварин виконували під час проведення загальноклінічного огляду за допомогою підлогових ваг TCS 2003 діапазоном вимірювання 0,05-200 кг. При оцінці частоти серцевих скорочень (ЧСС) враховували норми для різних вагових категорій: вага 1-10 кг (mini, ЧСС 120-160 уд/хв), вага 11-25 кг (medium, ЧСС 70-150 уд/хв) та собаки великих і гігантських порід, вага відповідно 26-44 кг (maxi) і більше 45 кг (giant), ЧСС даної групи тварин 60-130 уд/хв), а також ефект стресу (проводили вимірювання ЧСС методом аускультації до моменту запису ЕКГ). Під час аналізу електрокардіограм визначали ЧСС, регулярність серцевих скорочень, амплітуду і тривалість зубця Р, тривалість інтервалу PQ, оцінювали комплекс QRS. Усі досліджувані параметри оформили у три групи: оцінка серцевого ритму, провідності, процесів ремоделювання міокарда (Illarionova, 2006).

Отримані дані записували у протоколи дослідження з електрокардіографічними висновками. Усі розрахунки здійснювали на персональному комп'ютері, статистичну обробку одержаних результатів проводили за допомогою програмного забезпечення (програма StatWin та Excel 2010).

\section{Результати та їх обговорення}

Згідно з даними анамнезу, основними скаргами власників хворих собак були: непереносимість фізичних навантажень (90\% собак), зменшення тривалості щоденних прогулянок (85\%), тахіпное при незначних навантаженнях (83,3\%), втрата ваги (70\%), пригнічення (66 \%), гіпорексія (50\%), підвищена сонливість $(47,2 \%)$, тахіпное у стані спокою (25\%), кашель (18\%), неспокій (13,9\%), втарата свідомості $(2,8 \%)$.

За результатами клінічного огляду, у 52,8 \% собак реєстрували зміни в кон'юнктиві та слизовій оболонці рота: ціаноз, блідість, сухість, відхилення ШНК, що зумовлені зниженням хвилинного об'єму крові, анемією. У 25 \% тварин виявили позитивний трахеальний рефлекс і кашель як результат кардіомегалії 3 наступною компресією лівого бронхіального стовбура. У 66,6 \% собак діагностували видимі ознаки затримки рідини в організмі - тахіпное, диспное, збільшення об'єму черева, контурування яремних вен. При пальпації у 58,3 \% тварин дослідної групи виявили зміни серцевого поштовху і пульсу. За допомогою аускультації у 86,1 \% собак встановили зміни у ритмічності, тривалості та силі серцевих тонів (неритмічність, подовження, посилення, ослаблення, наявність шумів).

При аналізі ЕКГ-записів собак дослідної групи, у $72,2 \%$ тварин виявлено регулярний (правильний) ритм, у 27,8 \% - нерегулярний (неправильний). У 13,9 \% тварин нерегулярність викликана респіраторною аритмією, яка пов'язана з фазами дихання. Така фізіологічна варіабельність серцевого ритму у собак зумовлена підвищенням тонусу блукаючого нерва i його впливу на синоатріальний вузол, минає після фізичного навантаження i призначення атропіну (Illarionova, 2006; Oliveira et al., 2012; Vess, 2016). Згідно 3 літературними джерелами (Hanton \& Rabemampianina, 2006), зниження чи відсутність дихальної аритмії у тварин із хворобами серця $є$ предиктором прогресування ХСН.

При оцінці частоти ритму серця пришвидшення ЧСС загалом діагностували у 55,6 \% собак, а сповільнення - у 8,3 \%. Відповідно до аналізу отриманих показників ЧСС у ваговій групі 1-10 кг, у 4 тварин виявлено синусову тахікардію, у 2 - синусову брадикардію, у 4 - даний показник перебував у межах фізіологічної норми (рис. 1).

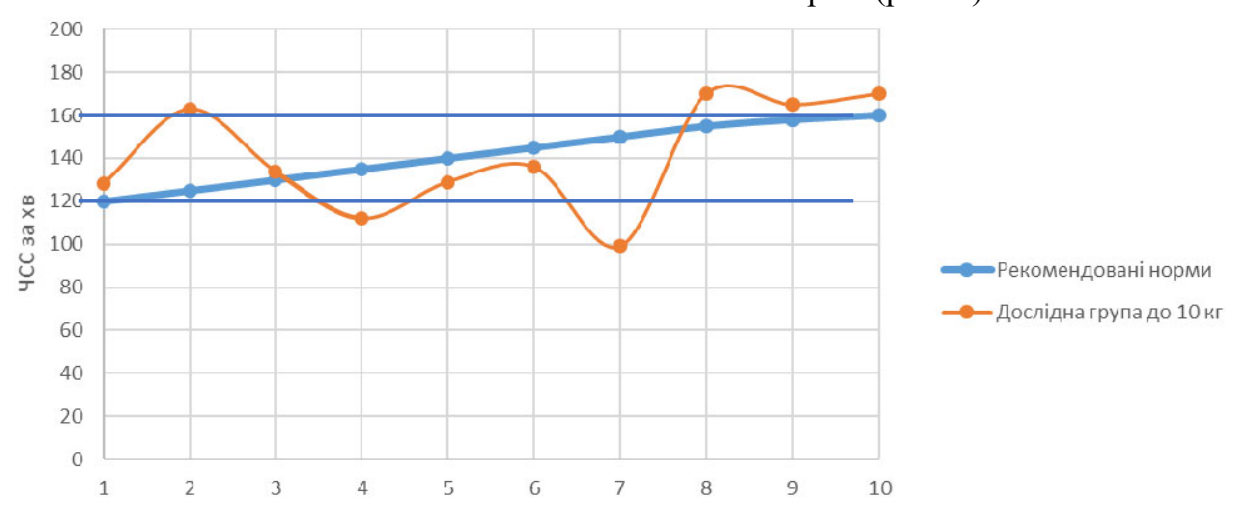

Рис. 1. Частота серцевих скорочень (уд/хв) дослідної групи тварин до 10 кг, $\mathrm{n}=10$ 
У ваговій категорії 11-25 кг у 5 тварин встановлено синусову тахікардію, в 1 - несинусового походження, а у 3 - ЧСС була в межах норми (рис. 2).

Серед вагової групи 26-44 кг у 6 тварин реєстрували синусову тахікардію, у 2 - несинусового похо- дження, в 1 - брадикардію. У 3 собак відхилень не виявлено. Водночас, зростання частоти серцевих скорочень у ваговій групі більше 45 кг виявили у 2 тварин (рис. 3).

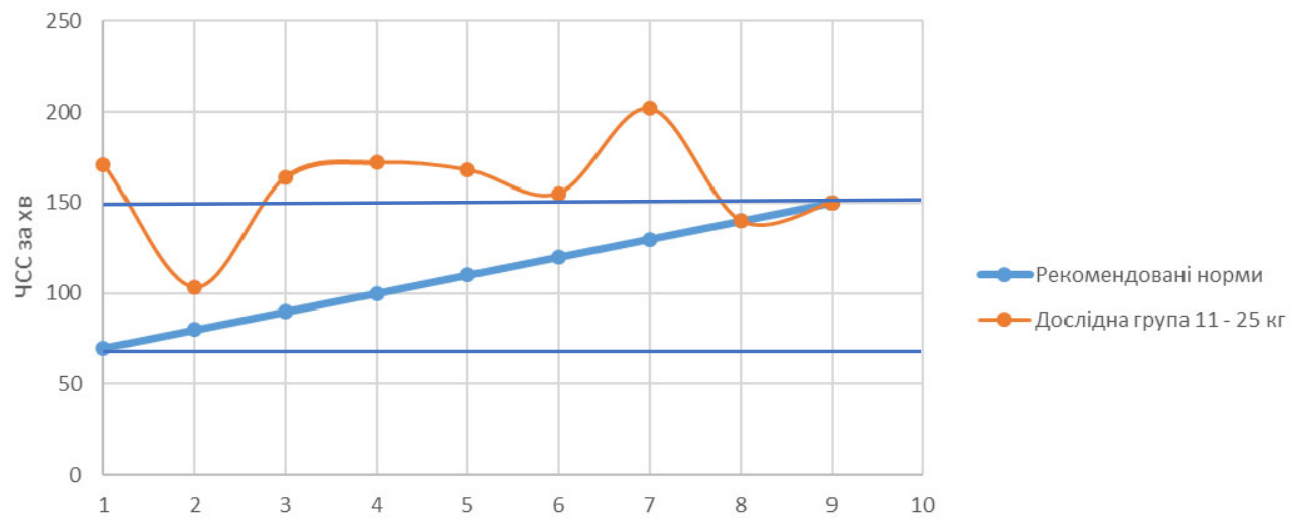

Рис. 2. Частота серцевих скорочень (уд/хв) дослідної групи тварин вагою 11-25 кг, n = 9

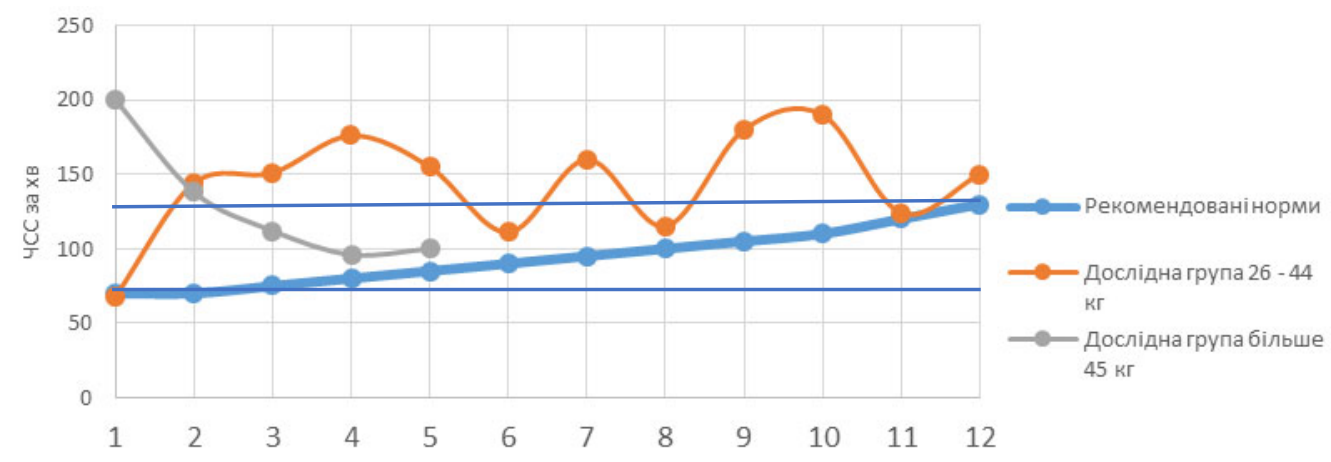

Рис. 3. Частота серцевих скорочень (уд/хв) дослідної групи тварин вагою 26-44 кг, n = 12 та більше 45 кг, $\mathrm{n}=5$

Синусову тахікардію можна розглядати як тимчасову компенсаторну відповідь серцевого м'яза на зміни артеріального тиску з метою підтримання перфузії внутрішніх органів (Baisan et al., 2016; Carvalho et al., 2018). Вона є результатом подразнення барорецепторів, розташованих у дузі аорти і каротидному синусі (Martin \& Korkorjen, 2010). Однак, за розвитку $\mathrm{XCH}$ виникає дисавтономія 3 наступним зростанням тонусу симпатичної нервової системи i, як наслідок, поява стійкої тахікардії (Oliveira et al., 2012; Vess, 2016; Bogucki \& Noszczyk-Nowak, 2017). Хронічна тахікардія супроводжується наростанням процесів декомпенсації, оскільки зменшується тривалість діастоли серця, а отже і його наповнення кров'ю, зниженням ударного об'єму і посиленням гіпоксії міокарда i внутрішніх органів (Carvalho et al., 2018). Подібні результати описані у дослідженнях Илларионовой В. (Illarionova, 2014), яка встановила, що прогресування ХCH супроводжується синусовою тахікардією і відсутністю дихальної аритмії. Сприятливим фактором розвитку синусової тахікардії $\epsilon$ анемія, яка, згідно $з$ результатами загальноклінічного аналізу крові, спостерігалась у 50,0 \% собак (Trofim'jak \& Slivins'ka, 2020). I лише у 5,6 \% тварин реєстрували синусову брадикардію як можливий наслідок підвищення парасимпатичного тонусу, зокрема в 1 собаки за гіпотире- озу. Порушення електролітного балансу $\left(\mathrm{K}^{+}, \mathrm{Na}^{+}\right.$, $\left.\mathrm{Ca}^{2+}\right)$ як причину синусової брадикардії виключили на основі аналізу показників біохімічного профілю сироватки крові тварин (Trofim'jak \& Slivins'ka, 2020).

При оцінці джерела збудження серця у 88,9 \% тварин дослідної групи виявлено синусовий ритм, який $\epsilon$ варіантом норми. У 5,6 \% реєстрували миготливу аритмію, в 2,8 \% - передсердний ритм, у 2,8 \% - ідіовентрикулярний ритм. Міграція водія ритму по передсердях у собак є нормою і часто асоціюється із респіраторною аритмією. Ідіовентрикулярний ритм наявний у тварини із пароксизмальною шлуночковою тахікардією, викликаною ушкодженнями міокарда шлуночка внаслідок ДКМП. Фібриляцію передсердь діагностуємо на пізніх стадіях ХCH 3 вираженою атріодилятацією (Aptekmann et al., 2010; Baisan et al., 2016). Остання виникає внаслідок хронічного перевантаження об'ємом крові через регургітацію за ЕМК, а також внаслідок розвитку структурних незворотніх змін (жирова інфільтрація, фіброз) в міокарді передсердь при ДКМП (Everett \& Olgin, 2007). Вищеперелічені морфологічні зміни супроводжуються електричним ремоделюванням міокарда передсердь, а саме: скорочення рефрактерного періоду, сповільнення швидкості поширення імпульсу та зміни у функціонуванні іонних каналів (Jung et al., 2016). Даний тип 
аритмії сприяє наростанню декомпенсації серцевої недостатності (Morales et al., 2001).

У 5,6 \% тварин із синусовим ритмом виявлено поодинокі мономорфні гемодинамічно незначні правошлуночкову і лівошлуночкову екстрасистоли.

Порушення провідності встановлено у 19,4 \% собак (табл. 1). Внутріпередсердна блокада (Voroncova, 2003; Illarionova, 2012; Savarino et al., 2012) виявлена у 11,1 \% хворих тварин, характеризувалася, як правило, подовженням зубця Р і зміною його конфігурації (роздвоєний, двофазний) (Cvilihovs'kij et al., 2010). Однак слід зауважити, що дані критерії також є непрямими показниками зміни розміру ЛП (P-mitrale) (Illarionova et al., 2006; Ford \& Mazzaferro, 2011; Kumar et al., 2014; Baisan et al., 2016; Bogucki \& Noszczyk-Nowak, 2017). Тому для диференціації тваринам додатково проводили скринінгове ехокардіог- рафічне обстеження. Атріовентрикулярну блокаду першого ступеня із подовженням інтервалу PQ $\geq 0,14$ секунд реєстрували у 5,6 \% дослідних собак, а у 2,8 \% тварин спостерігали поєднання внутріпередсердної блокади та АВ-блокади першого ступеня. На нашу думку, імовірними причинами $є$ ушкодження АВвузла і провідної системи передсердь внаслідок кардіоміопатій та підвищеного тонусу блукаючого нерва (Matveeva, 2005; Hanton \& Rabemampianina, 2006; Aptekmann et al., 2010). Також слід зазначити, що у 2,8 \% собак причиною АВ-блокади першого ступеня $\epsilon$ зростання рефрактерності АВ-вузла на фоні синусової тахікардії (Hanton \& Rabemampianina, 2006; Aptekmann et al., 2010). У 8,3 \% тварин провести оцінку провідності не вдалося у зв’язку з наявністю складних форм аритмій.

\section{Таблиця 1}

Тривалість електрокардіографічних показників у собак дослідної групи

\begin{tabular}{|c|c|c|c|c|}
\hline $\begin{array}{c}\text { Вагова група хворих } \\
\text { собак } \\
\end{array}$ & $\begin{array}{c}\text { Біометричний } \\
\text { показник } \\
\end{array}$ & $\begin{array}{c}\text { Тривалість зубця } \\
\text { Р, сек } \\
\end{array}$ & Інтервал PQ, сек & $\begin{array}{c}\text { Тривалість комплексу } \\
\text { QRS,сек } \\
\end{array}$ \\
\hline & $\mathrm{n}$ & 10 & 10 & 10 \\
\hline Min1 & Lim & $0,03-0,07$ & $0,06-0,13$ & $0,03-0,07$ \\
\hline$(1-10$ кг) & $\mathrm{M} \pm \mathrm{m}$ & $0,046 \pm 0,004$ & $0,103 \pm 0,007$ & $0,046 \pm 0,004$ \\
\hline & $\mathrm{n}$ & 8 & 8 & 9 \\
\hline (11-25 кг) & Lim & $0,02-0,06$ & $0,08-0,16$ & $0,02-0,08$ \\
\hline & $\mathrm{M} \pm \mathrm{m}$ & $0,046 \pm 0,005$ & $0,103 \pm 0,009$ & $0,053 \pm 0,007$ \\
\hline $\begin{array}{c}\text { Maxi } \\
(26-44 \text { кг) }\end{array}$ & $\begin{array}{c}n \\
\operatorname{Lim} \\
M \pm m\end{array}$ & $\begin{array}{c}10 \\
0,04-0,06 \\
0,05 \pm 0,030\end{array}$ & $\begin{array}{c}10 \\
0,09-0,13 \\
0,104 \pm 0,005\end{array}$ & $\begin{array}{c}11 \\
0,04-0,07 \\
0,054 \pm 0,003\end{array}$ \\
\hline $\begin{array}{c}\text { Giant } \\
\text { (більше } 45 \text { кг) }\end{array}$ & $\begin{array}{c}\mathrm{n} \\
\mathrm{Lim} \\
\mathrm{M} \pm \mathrm{m}\end{array}$ & $\begin{array}{c}5 \\
0,04-0,06 \\
0,052 \pm 0,005\end{array}$ & $\begin{array}{c}5 \\
0,08-0,14 \\
0,108 \pm 0,012\end{array}$ & $\begin{array}{c}5 \\
0,04-0,06 \\
0,050 \pm 0,003\end{array}$ \\
\hline
\end{tabular}

При аналізі електричної осі серця у дослідній групі встановили відхилення ЕОС вліво у 8,3 \% собак (ЕВС $<+40$ градусів) та вправо - у 2,8 \% (ЕВC $>+100$ градусів) (табл. 2). Лише в 2,8 \% тварин відхилення осі вліво дотично у поєднанні 3 іншими екгпараметрами може вказувати на дилятацію лівого шлуночка (ЛШ) (Illarionova et al., 2006; Ford \& Mazzaferro, 2011). У решті випадків відхилення осі від референтних значень ми не виявили інших екг-ознак зміни геометрії камер серця чи блокад ніжок пучка Гіса. Слід зазначити, що за одночасної дилятація обох шлуночків значення ЕВС перебуває у межах “псевдонорми" (Ford \& Mazzaferro, 2011), зменшуючи таким чином діагностичне значення даного параметра (Illarionova et al., 2006).

Таблиця 2

Амплітуди та ЕВС у собак дослідної групи

\begin{tabular}{ccccccc}
\hline $\begin{array}{c}\text { Вагова група } \\
\text { хворих собак }\end{array}$ & $\begin{array}{c}\text { Біометричний } \\
\text { показник }\end{array}$ & $\begin{array}{c}\mathrm{EBC}, \text { граду- } \\
\text { си }\end{array}$ & $\begin{array}{c}\text { Зубець } \mathrm{P} \\
\text { вольтаж } \mathrm{MB}\end{array}$ & $\begin{array}{c}\text { Зубець Q } \\
\text { вольтаж, } \mathrm{MB}\end{array}$ & $\begin{array}{c}\text { Зубець } \mathrm{S} \\
\text { вольтаж, } \\
\mathrm{MB}\end{array}$ & $\begin{array}{c}\text { Зубець } \mathrm{R} \\
\text { Вольтаж, Мв }\end{array}$ \\
\hline Mini & $\mathrm{n}$ & 10 & 9 & 10 & 10 & 10 \\
$(1-10$ кг) & $\mathrm{Lim}$ & $51-130$ & $0,2-0,5$ & $0,1-1,2$ & $0,1-0,5$ & $1,2-3,5$ \\
& $\mathrm{M} \pm \mathrm{m}$ & $67,80 \pm 8,35$ & $0,367 \pm 0,03$ & $0,43 \pm 0,11$ & $0,31 \pm 0,04$ & $2,04 \pm 0,28$ \\
Medium & $\mathrm{n}$ & 9 & 8 & 9 & 9 & 9 \\
$(11-25$ кг) & $\mathrm{Lim}$ & $15-90$ & $0,1-0,5$ & $0,3-1,7$ & $0,1-0,5$ & $1,1-3,4$ \\
& $\mathrm{M} \pm \mathrm{m}$ & $64,67 \pm 8,96$ & $0,363 \pm 0,06$ & $0,74 \pm 0,15$ & $0,23 \pm 0,05$ & $2,07 \pm 0,23$ \\
Maxi & $\mathrm{n}$ & 11 & 10 & 11 & 11 & 11 \\
$(26-44$ кг $)$ & $\mathrm{Lim}$ & $30-100$ & $0,2-0,6$ & $0,1-1,5$ & $0,1-0,4$ & $1,0-3,4$ \\
Giant & $\mathrm{M} \pm \mathrm{m}$ & $70,09 \pm 5,69$ & $0,370 \pm 0,04$ & $0,45 \pm 0,12$ & $0,24 \pm 0,03$ & $2,20 \pm 0,28$ \\
(більше 45 кг) & $\mathrm{n}$ & 5 & 5 & 5 & 5 & 5 \\
& $\mathrm{Lim}$ & $41-78$ & $0,2-0,5$ & $0,2-0,9$ & $0,1-0,4$ & $1,2-2,3$ \\
\hline
\end{tabular}


P-mitrale виявлено у 19,4 \% тварин, P-pulmonale у $16,7 \%$, екг-ознаки біатріального розширення (P $\geq$ 0,05 сек., $\mathrm{P}>0,4 \mathrm{mV}$, двогорбий $\mathrm{P}$ в II, III, aVF) зареєстровано у $5,6 \%$ хворих собак. Збільшення тривалості зубця P (P-mitrale) є непрямим показником дилятації ЛП (Matveeva, 2005; Ford \& Mazzaferro, 2011; Kumar et al., 2014; Baisan et al., 2016; Bogucki \& NoszczykNowak, 2017). Встановлено пряму залежність між розширенням зубця Р та ступенем збільшення порожнини ЛП на Ехо-Кг: лише при значному збільшенні ЛП (індекс розширення ЛП/Ао - 1,9 і вище) тривалість зубця Р перевищує референтні значення норми, тобто при незначній та помірній дилятації не реєструють змін у тривалості зубця Р на ЕКГ (Illarionova et al., 2006; Illarionova, 2014). Також виявлено позитивну кореляцію із прогресуванням ХCH (Rudenko, 2007). Чутливість даного діагностичного параметру становить $40 \%$, а специфічність - $93 \%$ (Savarino et al., 2012). Збільшення вольтажу зубця Р (P-pulmonale) вважається непрямим показником розширення або перевантаження ПП (Hanton \& Rabemampianina, 2006; Illarionova et al., 2006; Ford \& Mazzaferro, 2011; Kumar et al., 2014). Таким чином, у 41,7 \% собак виявляємо екг-ознаки збільшення розмірів обох передсердь.

Ремоделювання камер шлуночків зареєстровано у 38,8 \%. Причиною ремоделювання міокарда є тривала гіперактивація нейрогуморальної системи у відповідь на наростаюче зниження систолічної та/ або діастолічної функції серця із наступними змінами внутрісерцевої гемодинаміки (Illarionova, 2012). При аналізі ЕКГ, глибокі зубці Q виявлено у 38,9 \% тварин, що, у поєднанні із високовольтажними зубцями R, є ознакою гіпертрофії міокарда лівого шлуночка (Matveeva, 2005; Illarionova et al., 2006; Ford \& Mazzaferro, 2011; Illarionova, 2014). Розширення комплексу QRS, який є одним із ЕКГ-ознак дилятації порожнини ЛШ, виявлено в 16,7 \% (табл. 2) (Matveeva, 2005; Illarionova et al., 2006; Ford \& Mazzaferro, 2011).

Деформацій комплексу QRS у вигляді зазубрень на ЕКГ відзначаємо у 41,7 \% собак. При цьому, у $16,7 \%$ тварин зазубрення реєструємо в одному відведенні, в $11,1 \%$ - одночасно в двох різних відведеннях, в 8,3 \% - у трьох відведеннях, а в 5,6 \% - у чотирьох. Такі зміни, згідно з даними (Matveeva, 2005; Winter \& Bates, 2018), свідчать про порушення внутрішлуночкової провідності. Діагностичне значення має кількість виявлених відведень 3 деформованими комплексами QRS. У 22,2 \% випадках деформація QRS комплексу поєднується з P-mitrale, P-pulmonale, фібриляцією передсердь, збільшенням вольтажу i тривалості QRS, AB-блокадою I ступеня.

Відхилення сегмента ST вниз від ізоелектричної лінії більше ніж на 0,2 mV виявляємо у 25,0 \% собак. Депресія ST вказує на субендокардіальну ішемію та гіпоксію міокарда (Morales et al., 2001; Illarionova et al., 2006; Piccirillo et al., 2009; Ford \& Mazzaferro, 2011). Згідно з результатами дослідження (Matveeva, 2005), прогресування ХСН у собак призводить до подальшої інверсії сегменту ST внаслідок збільшенням часу проходження хвилі деполяризації від внут- рішніх до зовнішніх шарів стінок міокарда при збільшенні його маси. Ішемія наростає із зменшенням просвіту дрібних коронарних судин під впливом активації ренін-ангіотензин-альдостеронової системи (РАAC), а також на фоні прогресуючого зниження серцевого викиду. Також може поглиблюватися за рахунок тахіаритмій, котрі спричиняють значне зменшення часу діастолічного розслаблення міокарда шлуночків, а отже і його здатності наповнюватися необхідним об'ємом крові. При нетривалій ішемії обмін речовин у серцевому м'язі відновлюється, а при тривалому погіршенні кровопостачання міокарда гіпоксія прогресує і призводить до значного порушення процесів метаболізму у м'язових волокнах. Це проявляються, перш за все, розладами процесів реполяризації з наступним можливим розвитком злоякісних аритмій (Baisan et al., 2016; Santilli et al., 2018). Такі пацієнти потребують динамічного спостереження 3 обов'язковим проведенням повторного ЕКГобстеження (Matveeva, 2005).

Провівши комплексну оцінку електрокардіограм собак із $\mathrm{XCH}$, ми виявили наступні електрокардіографічні синдроми: порушення ритму (69,4 \%), порушення провідності (19,4 \%), дотичні ознаки процесів ремоделювання (63,9\%), ознаки ішемії (25\%).

\section{Висновки}

Частота аритмій за даними ЕКГ у собак із $\mathrm{XCH}$ складає 75,0 \%, із них 8,3 \% - загрозливі для життя, 38,9 \% із обстежених тварини потребують лікування, $27,8 \%$ - щорічного ЕКГ-моніторингу. Часто виникають аритмії внаслідок порушення збудливості та формування імпульсу. У структурі порушення ритму у собак за ХCH переважають синусова тахікардія $(47,2 \%)$, синусова брадикардія $(8,3 \%)$, шлуночкові екстрасистоли (5,6 \%), фібриляція передсердь (5,6 \%), шлуночкова тахікардія (2,8 \%). Порушення провідності реєструємо у вигляді внутріпередсердної блокади $(13,9 \%)$ та АВ-блокади I ступеня (8,3 \%). У 13,9 \% тварин ЕКГ-ознаки фіброзу, ішемії поєднуються із змінами розмірів камер серця.

Перспективи подальших досліджень. Для покращення діагностики та лікування виникає потреба у встановленні взаємозв'язку між ЕКГ- та ЕхоКГзмінами у собак із синдромом $\mathrm{XCH}$, які можуть бути як причиною $\mathrm{CH}$, так і їі наслідком та предиктором несприятливого прогнозу перебігу захворювання.

\section{References}

Aptekmann, K., Vailati, M., Fortuna, T., \& Schwartz, D. (2010). Prevalence of cardiac arrhythmias and conduction disturbances in dogs and cats in Botucatu, Brazil (2003-2007). Braz. J. Vet. Res. Anim. Sci., San Paulo, 47(5), 371-379. doi: 10.11606/issn.16784456.bjvras.2010.26818.

Baisan, R., Bîrsan, O., \& Vulpe, V. (2016) Electrocardiographic changes in chronic valvular disease and dilated cardiomyopathy in dog. HVM Bioflux, 8(2), 98-102. 
URL: $\quad$ http://www.hvm.bioflux.com.ro/docs/2015.98102.pdf.

Bogucki, Sz., \& Noszczyk-Nowak, A. (2017). Short-term heart rate variability in dogs with sick sinus syndrome or chronic mitral valve disease as compared to healthy controls. Pol. J. of Vet. Sci., 20(1), 167-172. doi: 10.1515/pjvs-2017-0021.

Bruler, B., Jojima, F., \& Dittrich, G. (2018). QT instability, an indicator of augmented arrhythmogenesis, increases with the progression of myxomatous mitral valve disease in dogs. J. of Vet. Card., 20(4), 254266. doi: 10.1016/j.jvc.2018.06.002.

Carvalho, E., Ampuero, R., \& Tuleski, G. (2018). Polymorphism, coupling interval and prematurity index in dogs with degenerative mitral valve disease and ventricular arrhythmias. Vet. Res. Comm., 42(2), 153160. doi: 10.1007/s11259-018-9718-0.

Cvilihovs'kij, M., Rudenko, A., \& Rudenko, P. (2010). Naukovo-praktychni rekomendatsii z elektrokardiohrafii sobak i kotiv. Kyiv (in Ukrainian).

Dutton, E., \& López-Alvarez, J. (2018). An update on canine cardiomyopathies - is it all in the genes? J. of Small Anim. Pract., 59(8), 455-464. doi: $10.1111 /$ jsap.12841.

Everett, T., \& Olgin, J. (2007). Atrial fibrosis and the mechanisms of atrial fibrillation. Heart Rhythm, 4(3), 24-27. doi: 10.1016\%2Fj.hrthm.2006.12.040.

Ford, R., \& Mazzaferro, E. (2011). Kirk \& Bistner's handbook of veterinary procedures and emergency treatment. Elsevier saunders, 9th edition, 784.

Hanton, G., \& Rabemampianina, Y. (2006). The electrocardiogram of the Beagle dog: reference values and effect of sex, genetic strain, body position and heart rate. Laboratory Animals, 40(2), 123-136. doi: 10.1258/002367706776319088.

Illarionova, V. (2006). Algoritmy interpretacii kardiogrammy sobak. Rossijskij veterinarnyj zhurnal. Melkie domashnie i dikie zhivotnye, 3, 20-26 (in Russian).

Illarionova, V. (2014). Miksomatoznaja degeneracija mitral'nogo klapana u jorkshirskih ter'erov. Ros. vet. zhur. Melkie domashnie i dikie zhivotnye, 3, 6-10 (in Russian).

Illarionova, V. (2017). Atrioventrikuljarnaja blokada serdca u sobak. Ros. vet. zhur. Melkie domashnie i dikie zhivotnye, 2, 10-12 (in Russian).

Illarionova, V. K. (2012). Serdechnaja nedostatochnost' u sobak. [Elektronnyj resurs]. Rezhim dostupa: https://www.youtube.com/watch?v=p6_ZYXoBjNw\& $\mathrm{t}=3807 \mathrm{~s}$ (in Russian).

Illarionova, V., Ippolitova, T., \& Denisenko, V. (2006). Kriterii diagnostiki i podhody $\mathrm{k}$ terapii hronicheskoj nedostatochnosti atrioventrikuljarnyh klapanov u sobak. Ros. vet. zhur. Melkie domashnie i dikie zhivotnye, 01, 21-26 (in Russian).

Jung, S., Sun, W., \& Griffiths, L. (2016). Atrial Fibrillation as a Prognostic Indicator in Medium to LargeSized Dogs with Myxomatous Mitral Valvular Degeneration and Congestive Heart Failure. J Vet Intern. Med., 30(1), 51-57. doi: 10.1111/jvim.13800.

Keene, B., Atkins, C., \& Bonagura, J. (2019). ACVIM consensus guidelines for the diagnosis and treatment of myxomatous mitral valve disease in dogs. J. Vet. Intern. Med., 33(3), 1127-1140. doi: 10.1111/jvim.15488.

Kim, H.-T., Han, S.-M., \& Song, S. W.-J. (2017). Retrospective study of degenerative mitral valve disease in smallbreed dogs: survival and prognostic variables. J Vet Sci., 18(3), 369-376. doi: 10.4142/jvs.2017.18.3.369.

Kumar, A., Dey, S., \& Mahajan, S. (2014). Incidence and Risk Assessment of Cardiac Arrhythmias in Dogs with Respect to Age, Breed, Sex and Associated Biochemical Changes. Advances in Animal and Veterinary Sciences, 2(5), 277-281. doi: 10.14737/journal.aavs/2014/2.5.277.281.

Martin, M., \& Korkorjen, B. (2010). Kardiorespiratornye zabolevanija sobak i koshek. Moskva: Akvarium Print (in Russian).

Martin, M., Johnson, M., \& Celona, B. (2009). Canine dilated cardiomyopathy: a retrospective study of signalment, presentation and clinical findings in 369 cases. J. of Small Anim. Pract., 50(1), 23-29. doi: 10.1111/j.1748-5827.2008.00659.x.

Matveeva, A. (2005). Diagnostika i lechenie ishemii miokarda u sobak. Materialy nauchno-prakticheskoj konferencii “Aktual'nye problemy patologii zhivotnyh", Barnaul, 57-60 (in Russian).

Meurs, K. (2017). Arrhythmogenic right ventricular cardiomyopathy in the Boxer dog: an update. Vet. Clin. Small Anim., 47(5), 1103-1111. doi: 10.1016/j.cvsm.2017.04.007.

Morales, M., Ynaraja, E., \& Montoya, J. (2001). Dilated Cardiomyopathy in Presa Canario Dogs: ECG Findings. J. Vet. Med., 48(10), 577-580. doi: 10.1046/j.1439-0442.2001.00395.x.

Noszczyk-Nowak, A., Michalek, M., \& Kaluza, E. (2017). Prevalence of Arrhythmias in Dogs Examined between 2008 and 2014. Journal of veterinary research, 61(1), 103-110. doi: 10.1515/jvetres-20170013.

Oliveira, M., Muzzi, R., \& Araújo, R. (2012). Heart rate variability parameters of myxomatous mitral valve disease in dogs with and without heart failure obtained using 24-hour Holter electrocardiography. Vet. Record, 170(24), 622. doi: 10.1136/vr.100202.

Paslawska, U., \& Kurski, B. (2008). Praktyczna elektrokardiografia malych zwierzat (atlas). Warszawa: Rexan, 123.

Piccirillo, G., Magri, D., \& Ogawa, M. (2009). Autonomic Nervous System Activity Measured Directly and QT Interval Variability in Normal and Pacing-Induced Tachycardia Heart Failure Dogs. JACC, 54(9), 840850. doi: 10.1016/j.jacc.2009.06.008.

Rudenko, A. (2007). Poshirennja supraventrikuljarnih aritmij u sobak. Zb. nauk. prac' Lugan. nac. agrar. untu., 78/101, 516-520 (in Ukrainian).

Rudenko, A. (2009). Variiuvannia normalnykh elektrokardiohrafichnykh parametriv vid masy tila sobak. Nauk. visn. Lviv. nats. un-tu vet. medytsyny ta biotekhnolohii im. S. Z. Gzhytskoho, 3(42), 113-118 (in Ukrainian).

Santilli, R., Moïse, N., Pariaut, R., \& Perego, M. (2018). Electrocardiography of the dog and cat. Diagnosis of arrhythmias. Edra S.p.A, 2nd edition, 360. 
Savarino, P., Borgarelli, M., \& Tarducci, A. (2012). Diagnostic performance of $\mathrm{P}$ wave duration in the identification of left atrial enlargement in dogs. J. of Small Anim. Pract., 53(5), 267-272. doi: 10.1111/j.17485827.2012.01200.x.

Tilley, L. (1992). Essentials of Canine and Feline Electrocardiography: Interpretation and Treatment. Philadelphia: Lea \& Febiger, 470.

Trofim'jak, R., \& Slivins'ka, L. (2020). Pokaznyky hemopoezu ta biokhimichnoho profiliu krovi sobak za khronichnoi sertsevoi nedostatnosti. Nauk. visnyk veterynarnoi medytsyny BNAU, 1(154), 63-71 (in Ukrainian).
Vess, G. (2016). Skrytaja dilatacionnaja kardiomiopatija u sobak: latentnaja stadija zabolevanija, nevidimaja vladel'cu. Ros. vet. zhur. Melkie domashnie i dikie zhivotnye, 4, 30-32 (in Russian).

Vollmar, A. (2000). The Prevalence of Cardiomyopathy in the Irish Wolfhound: A Clinical Study of 500 Dogs. J Am Anim Hosp Assoc., 36(2), 125-132. doi: 10.5326/15473317-36-2-125.

Voroncova, Ju. (2003). Vtorichnye formy aritmij i ih lechenie. Materialy 11-go Mezhdunarodnogo veterinarnogo kongressa, Moskva, 51 (in Russian).

Winter, R., \& Bates, R. (2018). Retrospective evaluation of notched QRS complexes in dogs: 85 cases. J. of Vet. Card., 20(1), 13-19. doi: 10.1016/j.jvc.2017.10.007. 